\title{
The County and State Taxing of the Koháry Demesnes in Hont County in the 1710's and 1720's
}

\author{
ZOLTÁN IGOR KOMJÁTI
}

\section{Private researcher, Abasár, Hungary}

Abstract: The campaigns against the Ottoman Empire and the War of Independence named after Francis Rákóczi lasting almost 30 years thoroughly ruined the economy of the Hungarian Kingdom by the beginning of the 1710's. The Sovereign (Charles the Third) and the governmental organizations tried to issue decrees for the constant development, but they almost all the time left out of consideration the difficult cost-of-living condition of the county inhabitants. The taxes imposed after "porta number" on the counties (gratuitous labour, winter quarters, billeting and conveyance for the transient army and doing wagon-traffic in the time of the Campaign of Báčka) were exactly supposed to fulfill by the county, so the Magistrate distributed to each settlements. The Koháry Family had two demesnes in the territory of Hont County: Čabrad' and Sitno, and the state and the county taxation applied to them in the same way as the other settlements. But Stephen (István) Koháry (directing Hont County as Lord-Lieutenant since 1711) always got an opportunity for acquiring the exemption of the demesnes from the gratuitous labour. Primarily, he had applied to Sovereign Charles the Third for issuing a diploma of exemption, then he introduced it with both the Hungarian Royal Locum-tenens Council and Hont County Magistrate. Thus, the two demesnes of Koháry were always exempted from the gratuitous labour, imposed and varied several times annually, and fulfilled either at Buda or Esztergom Fortresses. Last but not least, it can be observed that tendency that the existence of a diploma of exemption might not guarantee the automatic acceptance, in fact, it would be yearly applied for it, would be make it accepted on each occasion, and the acceptance of the exemption was the permanent item on the agenda of a county delegate negotiating with the higher authorities. The paper offers a deeper view into the the practice of the county taxation, and it sized up the economic life of Hont County in the first third of the $18^{\text {th }}$ century.

Keywords: payment of taxes, Hont County, Hungarian Kingdom, economic history, $18^{\text {th }}$ century.

DOI: https://doi.org/10.24040/ahn.2020.23.02.29-53

The Habsburg Government had a big challenge to face in 1711: it had to develop the Hungarian Kingdom economically to the level of the Hereditary Lands. This was not proved simple task, as the 16-yearslong course of the Ottoman Empire's dislodgement and the shortly after following War of Independence, with Francis Rákóczi as the leader of the insurgent army, almost entirely exhausted the economic resources 
of the population. ${ }^{1}$ There was a need for consequent, wise and purposeful taxation and economic policy for Hungary's rehabilitation again. ${ }^{2}$ But it was also essential that the Sovereign had to maintain a regular army in an efficient state to defend from external adversaries. The Government entailed the costs of the Regiments' marching, catering and winter quarters, moreover the costs of the construction works of the Fortresses on the Counties. ${ }^{3}$ Then the Counties distributed them among their districts and settlements.

In this text the light is thrown on the Magistrate's methods of imposing and exaction of the taxes, being necessary for running the Government and Hont County during the time of Stephen Koháry (1649-1731) as Lord-Lieutenant (supremus comes). At the same time, we can have a deeper view into the process of the procuring of tax exemption and the difficulties of the application and the enforcement, instancing the Kohárys' demesnes of Čabrad' and Sitno.

Joseph the First conferred the Lord-Lieutenant Office of Hont County on Stephen Koháry in the very beginning of 1711, but it lasted almost one year till his entry. The County suffered on account of the War of Independence, named after Rákóczi, as (the similarly Lord-Lieutenant) Wolfgang Koháry left this area, and soon such Magistrate assumed the authority which was allegiant to Rákóczi. Then the County turned into General Hannibal Heister's comandancia in 1709. So Hont County was highly expectant of Stephen Koháry's entry so the reconsolidation will have started off during his activity on all walks of life.

(I would like to thank to Hajnalka Tóth, Ph.D., for the helping with the translations of the gothic type lettered archival resources.)

\section{EXPENSES CONCERNING THE MILITARY PROVISIONS}

Hont County compiled those schedules of assessment lists which contained the sum of the Imperial soldiers' (oralis et equilis) portions being in winter quarters between $1^{\text {st }}$ of November, 1708 and $30^{\text {th }}$ of April, 1709, the common essential expenses of the County and the salary of the County Heyducks (summoners); but they did not contain the second correction of the tax-offer. On the strength of the lists, it was emerged that bigger taxes were imposed on several settlements, more than which was their duties. Mainly the settlements belonging to the District of Banská Štiavnica were concerned with this overtaxation, amid the Demesne of Sitno of the Koháry Family. ${ }^{4}$

\footnotetext{
1 MAGYARORSZÁG története 4/1., 1989, pp. 290-291.

2 In the same place, pp. 507.

${ }^{3}$ In the same place, pp. 596-597.

4 ŠABB, Hontianska župa, 4. škatul'a (Kongregačné zápisnice z rokov 1691-1754), schedules of assessment lists of Hont County (April of 1709).
} 
The County and State Taxing of the Koháry Demesnes in Hont County ...

\begin{tabular}{|l|c|c|}
\hline $\begin{array}{c}\text { Settlements of the } \\
\text { Demesne of Sitno }\end{array}$ & $\begin{array}{c}\text { Tax imposition } \\
\text { (in Rhenish forint and } \\
\text { denarius) }\end{array}$ & $\begin{array}{c}\text { Overpaid tax and } \\
\text { repayable money } \\
\text { (in Rhenish forint and } \\
\text { denarius) }\end{array}$ \\
\hline Svätý Anton (Szentantal) & 254 forints 25 denarii & none \\
\hline Žibritov (Zsibritó) & 339 forints & 448 forints 50 denarii \\
\hline Ilija (Illés) & 111 forints $871 / 2$ denarii & 365 forints \\
\hline $\begin{array}{l}\text { Sitnianska (Szitnyató or } \\
\text { Steffoltó) }\end{array}$ & 65 forints 56 denarii & 158 forints \\
\hline Krnišov (Kormosó) & 339 forints & 345 forints 50 denarii \\
\hline Beluj (Béld or Belluja) & 508 forints 50 denarii & 846 forints 50 denarii \\
\hline Prenčov (Berencsfalva) & 466 forints & 799 forints $871 / 2$ denarii \\
\hline $\begin{array}{l}\text { Sitnianska Lehôtka } \\
\text { (Szitnyaliget or Lehotka) }\end{array}$ & 84 forints 75 denarii & 128 forints 25 denarii \\
\hline Devičie (Devicse) & 203 forints $871 / 2$ denarii & 332 forints $12 \frac{1}{2} 2$ denarii \\
\hline Altogether & 2372 forints 81 denarii & 3423 forints 85 denarii \\
\hline
\end{tabular}

The villages of the Demesne of Čabrad'5 belonged to the Districts of Bzovík and Banská Štiavnica were obliged to pay the following tax sums.

\begin{tabular}{|c|c|c|c|}
\hline $\begin{array}{l}\text { Settlements of the } \\
\text { Demesne of Čabrad' }\end{array}$ & District & $\begin{array}{l}\text { Tax imposition } \\
\text { (in Rhenish forint } \\
\text { and denarius) }\end{array}$ & $\begin{array}{l}\text { Overpaid tax and } \\
\text { repayable money } \\
\text { (in Rhenish forint } \\
\text { and denarius) }\end{array}$ \\
\hline $\begin{array}{l}\text { Ipolyvece (Hungary, } \\
\text { Nógrád County) }\end{array}$ & Bzovík & 169 forints 50 denarii & none \\
\hline $\begin{array}{l}\text { Dolná Vinica } \\
\text { (Ipolyalsónyék) }\end{array}$ & Bzovík & 254 forints 25 denarii & none \\
\hline $\begin{array}{l}\text { Horná Vinica } \\
\text { (Ipolyfelsőnyék) }\end{array}$ & Bzovík & 169 forints 50 denarii & none \\
\hline Čelovce (Csall) & Bzovík & 339 forints & none \\
\hline $\begin{array}{l}\text { Opava (Apafalva or } \\
\text { Apova) }\end{array}$ & Bzovík & 254 forints 25 denarii & none \\
\hline $\begin{array}{l}\text { Ipel'ské Úl'any } \\
\text { (Ipolyfödémes) }\end{array}$ & Bzovík & $\begin{array}{l}127 \text { forints } 121 / 2 \\
\text { denarii }\end{array}$ & none \\
\hline $\begin{array}{l}\text { Čabradský Vrbovok } \\
\text { (Csábrágvarbók) }\end{array}$ & Bzovík & 254 forints 25 denarii & none \\
\hline Plášt’ovce (Palást) & $\begin{array}{l}\text { Banská } \\
\text { Štiavnica }\end{array}$ & 678 forints & none \\
\hline Slatina (Szalatnya) & $\begin{array}{l}\text { Banská } \\
\text { Štiavnica }\end{array}$ & 254 forints 25 denarii & none \\
\hline $\begin{array}{l}\text { Dolné Semerovce } \\
\text { (Alsószemeréd) }\end{array}$ & $\begin{array}{l}\text { Banská } \\
\text { Štiavnica }\end{array}$ & 111 forints 87 denarii & none \\
\hline $\begin{array}{l}\text { Vyškovce nad Ipl'om } \\
\text { (Ipolyvisk) }\end{array}$ & $\begin{array}{l}\text { Banská } \\
\text { Štiavnica }\end{array}$ & $\begin{array}{c}296 \text { forints } 621 / 2 \\
\text { denarii }\end{array}$ & none \\
\hline
\end{tabular}

${ }^{5}$ To the identifying of the settlements of the Demesne of Čabrad': SZIRÁCSIK, 2017, p. 30. 
Zoltán Igor Komjáti

\begin{tabular}{|l|c|c|c|}
\hline $\begin{array}{l}\text { Presel'any nad Ipl'om } \\
\text { (Pereszlény) }\end{array}$ & $\begin{array}{c}\text { Banská } \\
\text { Stiavnica }\end{array}$ & 254 forints 25 denarii & none \\
\hline $\begin{array}{l}\text { Medovarce } \\
\text { (Méznevelő) }\end{array}$ & $\begin{array}{c}\text { Banská } \\
\text { Štiavnica }\end{array}$ & 339 forints & none \\
\hline Altogether & & 3501 forints 87 denarii & \\
\hline
\end{tabular}

At bidding of Hont County, a committee was established in January, 1720 for determining the military tax rates imposed on each county settlements: on the one hand, concerning the expenses of the supplying and conveyance of the transient military (imputatio transennalis expensarum et vecturarum) from $1^{\text {st }}$ of January till $31^{\text {st }}$ of December, 1718; and on the other hand, concerning the alimentation expenses of the military staying in winter quarters (intertentionis quarterÿ) in the period lasting from $1^{\text {st }}$ of November, 1718. till $31^{\text {st }}$ of May, 1719. The expenses imposed on the Koháry-demesnes is the following 6 :

\begin{tabular}{|c|c|c|c|c|c|c|c|c|c|}
\hline \multirow[t]{2}{*}{ Settlement } & \multirow[t]{2}{*}{ 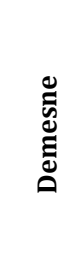 } & \multicolumn{2}{|c|}{ 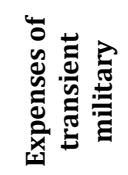 } & \multicolumn{2}{|c|}{ 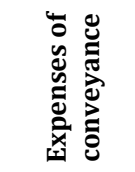 } & \multicolumn{2}{|c|}{ 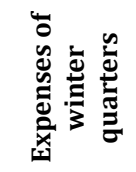 } & \multicolumn{2}{|c|}{ 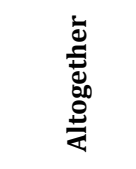 } \\
\hline & & $\mathrm{ft}$ & den & $\mathrm{ft}$ & den & $\mathrm{ft}$ & den & $\mathrm{ft}$ & den \\
\hline $\begin{array}{l}\text { Svätý Anton } \\
\text { (Szentantal) }\end{array}$ & Sitno & 18 & 39 & 81 & 75 & 247 & - & 347 & 14 \\
\hline $\begin{array}{l}\text { Žibritov } \\
\text { (Zsibritó) }\end{array}$ & Sitno & 47 & 4 & 132 & - & 563 & - & 742 & 7 \\
\hline Ilija (Illés) & Sitno & - & 54 & 83 & 50 & 294 & - & 378 & 4 \\
\hline $\begin{array}{l}\text { Sitnianska } \\
\text { (Szitnyatő or } \\
\text { Steffoltó) }\end{array}$ & Sitno & \multicolumn{8}{|c|}{ it does not figure on the assessment lists } \\
\hline $\begin{array}{l}\text { Krnišov } \\
\text { (Kormosó) }\end{array}$ & Sitno & 47 & $\begin{array}{l}51 \\
1 / 2\end{array}$ & 178 & - & 648 & 75 & 874 & $\begin{array}{l}26 \\
1 / 2\end{array}$ \\
\hline $\begin{array}{l}\text { Beluj (Béld or } \\
\text { Belluja) }\end{array}$ & Sitno & 39 & $\begin{array}{l}18 \\
1 / 2\end{array}$ & 242 & 50 & 817 & 75 & 1099 & $\begin{array}{l}43 \\
1 / 2 \\
\end{array}$ \\
\hline $\begin{array}{l}\text { Beluj (Béld or } \\
\text { Belluja): due to } \\
\text { the conflict with } \\
\text { the military }\end{array}$ & & - & - & - & - & 6 & 50 & 6 & 50 \\
\hline $\begin{array}{l}\text { Prenčov } \\
\text { (Berencsfalva) }\end{array}$ & Sitno & 31 & $\begin{array}{l}54 \\
1 / 2\end{array}$ & 257 & - & 659 & - & 947 & $\begin{array}{l}54 \\
1 / 2\end{array}$ \\
\hline
\end{tabular}

${ }^{6}$ ŠABB, Hontianska župa, 4. škatul'a (Kongregačné zápisnice z rokov 1691-1754), minutes of the tax determining committee of Hont County (Krupina, 8-9 th $^{\text {th }}$ January, 1720). 
The County and State Taxing of the Koháry Demesnes in Hont County ...

\begin{tabular}{|c|c|c|c|c|c|c|c|c|c|}
\hline $\begin{array}{l}\text { Sitnianska } \\
\text { Lehôtka } \\
\text { (Szitnyaliget or } \\
\text { Lehotka) }\end{array}$ & Sitno & 1 & 98 & 41 & 50 & 132 & 50 & 175 & 98 \\
\hline $\begin{array}{l}\text { Devičie } \\
\text { (Devicse) }\end{array}$ & Sitno & 18 & $\begin{array}{l}70 \\
1 / 2 \\
\end{array}$ & 147 & 50 & 398 & 17 & 564 & $\begin{array}{l}37 \\
1 / 2\end{array}$ \\
\hline $\begin{array}{l}\text { Ipolyvece (Hun- } \\
\text { gary, Nógrád } \\
\text { County) }\end{array}$ & Čabrad' & 107 & $\begin{array}{l}60 \\
1 / 2\end{array}$ & 112 & 75 & 362 & 50 & 582 & $\begin{array}{l}85 \\
1 / 2\end{array}$ \\
\hline $\begin{array}{l}\text { Dolná Vinica } \\
\text { (Ipolyalsónyék) }\end{array}$ & Čabrad' & 54 & $\begin{array}{l}28 \\
1 / 2\end{array}$ & 62 & 25 & 180 & 25 & 296 & $\begin{array}{l}78 \\
1 / 2\end{array}$ \\
\hline $\begin{array}{l}\text { Horná Vinica } \\
\text { (Ipolyfelsőnyék) }\end{array}$ & Čabrad' & 44 & 47 & 51 & - & 180 & 25 & 275 & 72 \\
\hline Čelovce (Csall) & Čabrad' & 18 & $\begin{array}{c}1 \\
1 / 2 \\
\end{array}$ & 65 & - & 551 & - & 634 & $\begin{array}{c}1 \\
1 / 2 \\
\end{array}$ \\
\hline $\begin{array}{l}\text { Opava (Apafalva } \\
\text { or Apova) }\end{array}$ & Čabrad' & 20 & 28 & 77 & 50 & 376 & - & 473 & 78 \\
\hline $\begin{array}{l}\text { Ipel'ské Úl'any } \\
\text { (Ipolyfödémes) }\end{array}$ & Čabrad' & \multicolumn{8}{|c|}{ it does not figure on the assessment lists } \\
\hline $\begin{array}{l}\text { Čabradský } \\
\text { Vrbovok } \\
\text { (Csábrágvarbók) }\end{array}$ & Čabrad' & 28 & 74 & 213 & - & 411 & - & 652 & 74 \\
\hline $\begin{array}{l}\text { Plášt'ovce } \\
\text { (Palást) }\end{array}$ & Čabrad' & 50 & 60 & 128 & 75 & 452 & 50 & 631 & 85 \\
\hline $\begin{array}{l}\text { Plášt'ovce (Pa- } \\
\text { lást): due to the } \\
\text { conflict with the } \\
\text { military }\end{array}$ & & - & - & - & - & 3 & 60 & 3 & 60 \\
\hline $\begin{array}{l}\text { Slatina } \\
\text { (Szalatnya) }\end{array}$ & Čabrad' & 27 & $\begin{array}{l}84 \\
1 / 2\end{array}$ & 98 & 50 & 220 & - & 346 & $\begin{array}{l}34 \\
1 / 2\end{array}$ \\
\hline $\begin{array}{l}\text { Slatina } \\
\text { (Szalatnya): due } \\
\text { to the conflict } \\
\text { with the military }\end{array}$ & & - & - & - & - & - & 60 & - & 60 \\
\hline $\begin{array}{l}\text { Dolné Seme- } \\
\text { rovce (Alsósze- } \\
\text { meréd) }\end{array}$ & Čabrad' & 113 & $\begin{array}{l}65 \\
1 / 2\end{array}$ & 244 & 50 & 387 & 50 & 745 & $\begin{array}{l}65 \\
1 / 2\end{array}$ \\
\hline $\begin{array}{l}\text { Vyškovce nad } \\
\text { Ipl'om } \\
\text { (Ipolyvisk) }\end{array}$ & Čabrad' & 144 & 98 & 199 & 50 & 490 & - & 804 & 48 \\
\hline $\begin{array}{l}\text { Presel’any nad } \\
\text { Ipl'om } \\
\text { (Pereszlény) }\end{array}$ & Čabrad' & 217 & 69 & 170 & - & 357 & 50 & 745 & 19 \\
\hline $\begin{array}{l}\text { Medovarce } \\
\text { (Méznevelő) }\end{array}$ & Čabrad' & 26 & 28 & 176 & - & 394 & $\begin{array}{l}91 \\
1 / 2\end{array}$ & 597 & $\begin{array}{l}19 \\
1 / 2\end{array}$ \\
\hline Altogether & & 1059 & $\begin{array}{l}34 \\
1 / 2\end{array}$ & 2762 & 50 & 8134 & $\begin{array}{l}28 \\
1 / 2\end{array}$ & 11956 & 13 \\
\hline
\end{tabular}


In spring of 1721, the Hungarian Royal Locum-tenens Council ordered Hont County to provide the Hannover Cuirassier Regiment for the period lasting till $1^{\text {st }}$ of May. The County Magistrate and the commissioned personnel of the regiment agreed that one portion equals with 44 dicas. $^{7}$ Nicholas Dvornikovics, Deputy-Lieutenant (vice-comes), made Stephen Koháry aware of that the agreement had come about on $24^{\text {th }}$ of March, and also sent him the list of the portion numbers belonged to each county settlements. ${ }^{8}$ On the basis of the list, the Koháry demesnes took part in the providing of the Hannover Regiment as follows. ${ }^{9}$

\begin{tabular}{|c|c|c|c|c|}
\hline Settlement & $\begin{array}{c}\text { De- } \\
\text { mesne }\end{array}$ & $\begin{array}{l}\text { Rank and unit of the } \\
\text { provided person(s) }\end{array}$ & $\begin{array}{l}\text { Oralis } \\
\text { portio }\end{array}$ & $\begin{array}{l}\text { Equilis } \\
\text { portio }\end{array}$ \\
\hline $\begin{array}{l}\text { Svätý Anton } \\
\text { (Szentantal) }\end{array}$ & Sitno & captain, cuirassier squadron & $2 \frac{1}{2}$ & 1 \\
\hline $\begin{array}{l}\text { Žibritov } \\
\text { (Zsibritó) }\end{array}$ & Sitno & $\begin{array}{l}\text { corporal, cuirassier squadron } \\
\text { cavalrymen, cuirassier squadron }\end{array}$ & $\begin{array}{c}1 \frac{1}{2} \\
4\end{array}$ & $\begin{array}{l}1 \\
-\end{array}$ \\
\hline Ilija (Illés) & Sitno & sub-lieutenant, cuirassier squadron & 2 & 2 \\
\hline $\begin{array}{l}\text { Sitnianska } \\
\text { (Szitnyatő or } \\
\text { Steffoltó) }\end{array}$ & Sitno & $\begin{array}{l}\text { sub-lieutenant, cuirassier squadron } \\
\text { cavalrymen, cuirassier squadron }\end{array}$ & $\begin{array}{l}- \\
1\end{array}$ & $\begin{array}{l}1 \\
-\end{array}$ \\
\hline $\begin{array}{l}\text { Krnišov } \\
\text { (Kormosó) }\end{array}$ & Sitno & captain, cuirassier squadron & $4 \frac{1}{2} 2$ & 3 \\
\hline $\begin{array}{l}\text { Beluj } \\
\text { (Béld or Belluja) }\end{array}$ & Sitno & corporal, cuirassier squadron & $1 \frac{1}{2}$ & 1 \\
\hline $\begin{array}{l}\text { Prenčov } \\
\text { (Berencsfalva) }\end{array}$ & Sitno & $\begin{array}{l}\text { quartermaster, cuirassier squadron } \\
\text { cavalrymen, cuirassier squadron }\end{array}$ & $\begin{array}{l}2 \\
6\end{array}$ & $\begin{array}{l}2 \\
-\end{array}$ \\
\hline $\begin{array}{l}\text { Sitnianska } \\
\text { Lehôtka } \\
\text { (Szitnyaliget or } \\
\text { Lehotka) }\end{array}$ & Sitno & captain, cuirassier squadron & - & 2 \\
\hline $\begin{array}{l}\text { Devičie } \\
\text { (Devicse) }\end{array}$ & Sitno & $\begin{array}{l}\text { squadron clerk, cuirassier squadron } \\
\text { cavalrymen, cuirassier squadron }\end{array}$ & $\begin{array}{l}1 \\
3\end{array}$ & $\begin{array}{l}2 \\
-\end{array}$ \\
\hline $\begin{array}{l}\text { Ipolyvece } \\
\text { (Hungary, Nó- } \\
\text { grád County) }\end{array}$ & Čabrad' & $\begin{array}{l}\text { captain, regimental commander's } \\
\text { squadron } \\
\text { cavalrymen, regimental commander's } \\
\text { squadron }\end{array}$ & - & $\begin{array}{l}3 \\
-\end{array}$ \\
\hline
\end{tabular}

\footnotetext{
7 The meaning of „dica”, see: POÓR, 2009, p. 40.

${ }^{8}$ MNL-OL C $756^{\text {th }}$ roll № 374., (ŠABB, Archive of the Koháry Family, Pars IV.), Nicholas Dvornikovics's letter to Stephen Koháry (Lontov, $2^{\text {nd }}$ of April, 1721).

${ }^{9}$ In the same place, enclosure of № 374, list of the settlements of Hont County ordered to supply the Cuirassier Regiment of Hannover (24th of March, 1721).
} 
The County and State Taxing of the Koháry Demesnes in Hont County ...

\begin{tabular}{|c|c|c|c|c|}
\hline $\begin{array}{l}\text { Dolná Vinica } \\
\text { (Ipolyalsónyék) }\end{array}$ & Čabrad' & $\begin{array}{l}\text { cavalrymen, regimental commander's } \\
\text { squadron }\end{array}$ & 2 & - \\
\hline $\begin{array}{l}\text { Horná Vinica } \\
\text { (Ipolyfelsőnyék) }\end{array}$ & Čabrad' & $\begin{array}{l}\text { cavalrymen, regimental commander's } \\
\text { squadron }\end{array}$ & 2 & - \\
\hline Čelovce (Csall) & Čabrad' & $\begin{array}{l}\text { lieutenant, regimental commander's } \\
\text { squadron }\end{array}$ & 2 & - \\
\hline $\begin{array}{l}\text { Opava (Apafalva } \\
\text { or Apova) }\end{array}$ & Čabrad' & $\begin{array}{l}\text { captain, regimental commander's } \\
\text { squadron } \\
\text { cavalrymen, regimental commander's } \\
\text { squadron } \\
\end{array}$ & $\overline{-}$ & $\begin{array}{l}3 \\
-\end{array}$ \\
\hline $\begin{array}{l}\text { Ipel'ské Úl'any } \\
\text { (Ipolyfödémes) }\end{array}$ & Čabrad' & cavalrymen, Lutzenthal Squadron & 2 & - \\
\hline $\begin{array}{l}\text { Čabradský } \\
\text { Vrbovok } \\
\text { (Csábrágvarbók) }\end{array}$ & Čabrad' & $\begin{array}{l}\text { drum-major, staff squadron } \\
\text { regimental doctor, staff squadron }\end{array}$ & $\overline{2}$ & $\begin{array}{l}1 \\
2\end{array}$ \\
\hline $\begin{array}{l}\text { Plášt'ovce } \\
\text { (Palást) }\end{array}$ & Čabrad' & $\begin{array}{l}\text { squadron clerk, Lutzenthal Squadron } \\
\text { cavalrymen, Lutzenthal Squadron }\end{array}$ & - & $\begin{array}{l}1 / 2 \\
-\end{array}$ \\
\hline $\begin{array}{l}\text { Slatina } \\
\text { (Szalatnya) }\end{array}$ & Čabrad' & $\begin{array}{l}\text { lieutenant, Lutzenthal Squadron } \\
\text { cavalrymen, Lutzenthal Squadron }\end{array}$ & $\begin{array}{l}1 \\
1\end{array}$ & $\begin{array}{l}1 \\
-\end{array}$ \\
\hline $\begin{array}{l}\text { Dolné Semerovce } \\
\text { (Alsószemeréd) }\end{array}$ & Čabrad' & $\begin{array}{l}\text { lieutenant, Lutzenthal Squadron } \\
\text { cavalrymen, Lutzenthal Squadron }\end{array}$ & $\begin{array}{l}2 \\
1\end{array}$ & $\begin{array}{l}2 \\
-\end{array}$ \\
\hline $\begin{array}{l}\text { Vyškovce nad } \\
\text { Ipl'om } \\
\text { (Ipolyvisk) }\end{array}$ & Čabrad' & cavalrymen, Lutzenthal Squadron & 5 & - \\
\hline $\begin{array}{l}\text { Presel'any nad } \\
\text { Ipl'om } \\
\text { (Pereszlény) }\end{array}$ & Čabrad' & $\begin{array}{l}\text { captain, Lutzenthal Squadron } \\
\text { cavalrymen, Lutzenthal Squadron }\end{array}$ & $\begin{array}{l}3 \\
1\end{array}$ & $\begin{array}{l}1 \\
-\end{array}$ \\
\hline $\begin{array}{l}\text { Medovarce } \\
\text { (Méznevelő) }\end{array}$ & Čabrad' & cavalrymen, Lutzenthal Squadron & 5 & - \\
\hline Altogether & & & 66 & $28 \frac{1}{1 / 2}$ \\
\hline $\begin{array}{l}\text { Portio number } \\
\text { imposed on the } \\
\text { whole County }\end{array}$ & & & $409 \frac{1}{2}$ & 67 \\
\hline
\end{tabular}

If we can examine the quantity of the portio number imposed on the Koháry-settlements for the providing of each units, we can ascertain the following contexts.

\begin{tabular}{|c|c|c|c|c|}
\hline $\begin{array}{c}\text { Name of the } \\
\text { Squadron }\end{array}$ & $\begin{array}{c}\text { Total of } \\
\text { oralis } \\
\text { portio for } \\
\text { the Squad- } \\
\text { ron }\end{array}$ & $\begin{array}{c}\text { Total of } \\
\text { equilis } \\
\text { portio for } \\
\text { the Squad- } \\
\text { ron }\end{array}$ & $\begin{array}{c}\text { Oralis portio } \\
\text { imposed on } \\
\text { the Koháry- } \\
\text { settlements }\end{array}$ & $\begin{array}{c}\text { Equilis portio } \\
\text { imposed on } \\
\text { the Koháry- } \\
\text { settlements }\end{array}$ \\
\hline $\begin{array}{c}\text { Staff } \\
\text { Squadron }\end{array}$ & 34 & 40 & 2 & 3 \\
\hline
\end{tabular}


Zoltán Igor Komjáti

\begin{tabular}{|c|c|c|c|c|}
\hline $\begin{array}{c}\text { Regimental } \\
\text { Commander's } \\
\text { Squadron }\end{array}$ & 37 & 21 & 9 & 6 \\
\hline $\begin{array}{c}\text { Cuirassier } \\
\text { Squadron }\end{array}$ & 126 & 32 & 29 & 15 \\
\hline $\begin{array}{c}\text { Lutzenthal } \\
\text { Squadron }\end{array}$ & 121 & 47 & 26 & $41 / 2$ \\
\hline
\end{tabular}

Due to the several enormous burdens, the bondage fulfilled the taxation hard, so its debts were often more and more aggregated. The county audit office (censuralis deputatio) which was established in the summer of 1713 and being at work till the following General Assembly, took cognizance of the fact that several villages had partly paid their taxes for the supplying of the Somodi Regiment on the basis of Amery Petróczy's tax roll. Krnišov was in debt with 3 forints and 50 denarii, Ilija with 39 forints and 50 denarii, Sitnianska Lehôtka with 2 forints and 19 denarii, Pláštovce with 43 forints and 19 denarii, Sitnianska Lehôtka with 10 forints and Svätý Anton with 48 forints. The inhabitants swore to the truth of paying their all debts: partly to the Somodisoldiers, partly to the since that defuncted John Trajtler, tax-collector. But as the villagers could not adduce proof of the quantity of the paid sum, so that will be considered as overpaid money in case of an accidental, further taxation. ${ }^{10}$

The tax-collectors saw the inhabitants of Čabradský Vrbovok one after another about their default of two kinds of debts in summer of 1714. Firstly, the villagers complained to Paul Návay, because their toll had not been paid so far according to the toll-collector's roll, and he encashed 3 forints from one of them. In the opinion of Paul Návay, the inhabitants of Čabradský Vrbovok only then exclaim against the tolling, if the fact of the agreement between the county and them, or any exemption is marked in the terrier (urbarium). As none of such mark can be found in it concerning the village, thus it is clearly seen, that their toll will have been paid, only if Stephen Koháry has some official document of exemption or some documents by means of it, would change the county agreement. ${ }^{11}$ Nearly in that time, some villagers of Čabradský Vrbovok went to Stephen Koháry and complained to him that they were blamed for being behindhand with the paying the expenses of the military billeting, and the county immediately demanded that sum, which was injustice by the villagers' opinion. Stephen Koháry

\footnotetext{
10 ŠABB, Hontianska župa, 4. škatul'a (Kongregačné zápisnice z rokov 1691-1754), minutes of Hont County Audit Office (Krupina, $8^{\text {th }}$ of June, 1713).

${ }_{11}$ MNL-OL C 754 th roll № 216., (ŠABB, Archive of the Koháry Family, Pars IV.), Paul Návay's letter to Stephen Koháry (Bzovík, 27th of June, 1714).
} 
immediately wrote a letter to Leslie Dobay county tax-collector (perceptor), asking for information whether the dwellers of Čabradský Vrbovok are really debtors of the county? The tax-collector reported upon the fact: in the time of the latest military billeting, the county had allocated Krnišov and Devičie as such „substitute places”, where the soldiers beyond the fore-announced quantity will be lodged. The county could not direct any soldiers to that settlements. But the Hungarian officer commanding that unit of the Esterházy Regiment billetted to Krupina (Korpona), wanted to get lodge for his German comrades, and all the time he bothered Dobay for an allocation of a free village (assignatio). As Dobay was not authorized to arranging, so he suggested him to apply to the Deputy-Lieutenant and the District Guiders (iudex nobilium or iudlium), and most likely they would sent the German military to Čabradský Vrbovok. And as regard the debt, the villagers really obliged to pay to the County, what Dobay itemized to Koháry. The tax proportion of Čabradský Vrbovok imposed by the County (obtingens) was 460 Rhenish forints and 12 and $1 / 2$ denarii, from which 306 Rhenish forints had been paid in cash by the villagers. Then the settlement had also handed over 76 Rhenish forint and 44 denarii to Samuel Blaskovics district guider (iudex nobilium) for its proportion of the catering of the military of the Regiment Viard and Regiment Esterházy being in winter quarters, and supplying of the transient military marching through the County in the period lasted from $1^{\text {st }}$ of November, 1713. till $30^{\text {th }}$ of April, 1714. Thus, the inhabitants of Čabradský Vrbovok really were in the County's debt with 77 forints and 68 denarii. ${ }^{12}$

\section{DEBTS CONCERNING THE CHAMBER OF BANSKÁ ŠTIAVNICA}

At the request of the Chamber of Banská Štiavnica, Hont County directed settlements several times to take part in the mining work since the autumn of 1708. The economic and regional consolidation after the Liberation War named after Ferenc Rákóczi materialized only slowly. For example, this can be seen from the fact, that though the County counted up the repayable money for the overfulfilled mining works and promised the concerned villages to give back that sum in any case. But that sum was inconsecutively re-distributed among the settlements by them, moreover, the County strictly exacted all kind of other taxes from the settlements, albeit they had dire needs for that sum to arrange the former demands. That problem especially bore upon the Koháry demesnes in 1713: as they were situated geographically nearer to the adits and shafts of Banská Štiavnica (Selmecbánya or Schemnitz), so the

\footnotetext{
12 In the same place, № 217., Leslie Dobay’s letter to Stephen Koháry (Krupina, 29 ${ }^{\text {th }}$ of June, 1714).
} 
County most of all primarily directed that villages to carry out the mining works between 1708 and 1712. The villages took out loans to pay for the military and county taxes (impositio), and due to the paying off with the interests, they almost totally ran into debt. By the decision of the County (punctually after, when the villages of the two Koháry demesnes met their debts with the interests) certain Hontian settlements got the repayable money for the overfulfilled mining works, more than 55 thousand forints. But it was financed by the County from the formerly collected taxes, amid the money which was discussed from the settlements of the two demesnes. And what is more, on the basis of the tax roll of the County tax-collector, the villages of the Koháry demesnes were still in debt with the payment of the „impositio”, so they were menaced by him with money execution. Stephen Koháry wrote a letter to the County Magistrate, drew its attention to the aforesaid facts, and asked the Magistrate not to collect any taxes from the settlements of his demesnes (mainly the „portio" for the winter quarter) as long as they would not get back the money originated from the overfulfilled mining works. ${ }^{13}$

The unsystematical overtaxing also continued in 1714, and therefore a deputation of the inhabitants of Žibritov and Devičie applied to Koháry as their landlord for help in August. The two villages were exacted to pay for the behindhand mining works several times previously, so they were compelled to take out a loan of 200 forints from John Trajtler for covering their debts to the County. But later the County also exacted this sum for the two villages again, because the since that defuncted John Trajtler marked that sum as a debt in his account. Thus, it was distressing for the villages that they previously was debt in several hundreds of forints, which now was more increased. Stephen Koháry asked Stephen Kelkó, Deputy-Lieutenant, to draw the County Magistrate on anulling that debt of 200 forints, and „...You do not let the villagers fall on evil days with overtaxations over and over again...". ${ }^{14}$

After all, at the summer of 1715 , Hont County systemized the total cost of the mining-works fulfilled between 1708 and 1712, and made a decision about re-paying the money being equivalent to the price of the over-fulfilled works for all of the settlements. Certain settlements belonging to the Districts of Banská Štiavnica and Bzovík sent draughthorses to the mines, and gave diggers and labourers for actuating the

\footnotetext{
13 ŠABB, Hontianska župa, 3. škatul'a (Torzo spisov z rokov 1708-1756), Stephen Koháry's letter to Hont County (Čabrad', $24^{\text {th }}$ of October, 1713).

${ }_{14}$ MNL-OL C 1123rd roll № 7087., (ك̌ABB, Archive of the Koháry Family, Pars V.), Stephen Koháry's letter to Stephen Kelkó, Deputy-Lieutenant of Hont County (Čabrad', 23 ${ }^{\text {rd }}$ of August, 1714). The original Hungarian text is the following: „....ne engedje a supererogatumokon felül ezen supererogatumoknak [a 200 forintnak] is exactiojával óket pusztulásra jutni...".
} 
The County and State Taxing of the Koháry Demesnes in Hont County ...

mine equipments in the period lasting from $1^{\text {st }}$ of November, 1708 to $31^{\text {st }}$ of October, 1710.15 The Chamber of Banská Štiavnica did not give them back any money at all, but they were compensated with counting in the half price of their journey-work. That means the following items concerning the Koháry demesnes:

\begin{tabular}{|l|c|}
\hline $\begin{array}{c}\text { The settlements of the } \\
\text { Demesne of Sitno }\end{array}$ & The sum to be repaid between $\mathbf{1 7 0 8}$ and $\mathbf{1 7 1 0}$ \\
\hline Svätý Anton (Szentantal) & 382 forints and 50 denarii \\
\hline Žibritov (Zsibritó) & 501 forints and 83 denarii \\
\hline Ilija (Illés) & 216 forints and 12 denarii \\
\hline $\begin{array}{l}\text { Sitnianska (Szitnyatő or } \\
\text { Steffoltó) }\end{array}$ & 67 forints and 50 denarii \\
\hline Krnišov (Kormosó) & 499 forints and 77 denarii \\
\hline Beluj (Béld or Belluja) & 675 forints and 80 denarii \\
\hline Prenčov (Berencsfalva) & 619 forints and $501 / 2$ denarii \\
\hline $\begin{array}{l}\text { Sitnianska Lehôtka } \\
\text { Szitnyaliget or Lehotka) }\end{array}$ & 67 forints and 50 denarii \\
\hline Devičie (Devicse) & none \\
\hline Altogether & 3030 forints and $521 / 2$ denarii \\
\hline
\end{tabular}

Then the Chamber of Banská Štiavnica deducted the quantity of the "portio" taxation form for the period lasted from 29th of November, 1710 to $25^{\text {th }}$ of April, 1711, and gave Jacob Othi, Military Commissioner of Hont County, back a sum of 2158 Rhenish forints and 35 1/2 denarii. That sum was forwarded by him to the county tax-collector (perceptor) who counted in the tax sum of the settlements. That concerned the Koháry demesnes so:

\begin{tabular}{|l|l|c|}
\hline \multicolumn{1}{|c|}{ Name of the settlement } & Demesne & $\begin{array}{c}\text { The sum to be repaid for } \\
\text { the year of 1710/1711 }\end{array}$ \\
\hline $\begin{array}{l}\text { Ipolyvece (Hungary, Nógrád } \\
\text { County) }\end{array}$ & Čabrad' & none \\
\hline Dolná Vinica (Ipolyalsónyék) & Čabrad' & none \\
\hline Horná Vinica (Ipolyfelsőnyék) & Čabrad' & none \\
\hline Čelovce (Csall) & Čabrad' & 26 forints and 32 1/2 denarii \\
\hline Opava (Apafalva or Apova) & Čabrad' & 14 forints and 83 denarii \\
\hline Ipel'ské Úl'any (Ipolyfödémes) & Čabrad' & none \\
\hline $\begin{array}{l}\text { Čabradský Vrbovok } \\
\text { (Csábrágvarbók) }\end{array}$ & Čabrad' & none \\
\hline Plášt'ovce (Palást) & Čabrad' & none \\
\hline
\end{tabular}

${ }^{15}$ MNL-OL C $1191^{\text {st }}$ roll, second enclosure of № 8369, (ك̌ABB, Archive of the Koháry Family, Pars V.), account of the fulfilling works of the settlements of Hont County between 1708 and 1710. 
Zoltán Igor Komjáti

\begin{tabular}{|l|c|c|}
\hline Slatina (Szalatnya) & Čabrad' & none \\
\hline Dolné Semerovce (Alsószemeréd) & Čabrad' & none \\
\hline Vyškovce nad Ipl'om (Ipolyvisk) & Čabrad' & none \\
\hline $\begin{array}{l}\text { Presel'any nad Ipl'om } \\
\text { (Pereszlény) }\end{array}$ & Čabrad' & none \\
\hline Medovarce (Méznevelő) & Čabrad' & S1 forints and 72 denarii \\
\hline Svätý Anton (Szentantal) & Sitno & Sorints \\
\hline Žibritov (Zsibritó) & Sitno & none \\
\hline Ilija (Illés) & Sitno & 32 forints and 10 denarii \\
\hline Sitnianska (Szitnyatő or Steffoltó) & Sitno & 54 forints and 85 denarii \\
\hline Krnišov (Kormosó) & Sitno & 105 forints and 40 denarii \\
\hline Beluj (Béld or Belluja) & Sitno & 98 forints and 95 denarii \\
\hline Prenčov (Berencsfalva) & Sitno & 13 forints and 60 denarii \\
\hline $\begin{array}{l}\text { Sitnianska Lehôtka (Szitnyaliget } \\
\text { or Lehotka) }\end{array}$ & Sitno & 22 forints and 15 denarii \\
\hline Devičie (Devicse) & Sitno & 459 forints and $921 / 2$ denarii \\
\hline Altogether & \multicolumn{2}{|l}{} \\
\hline
\end{tabular}

The statute-labour of the Hont County settlements toward the Chamber of Banská Štiavnica was fulfilled till $12^{\text {th }}$ of November, 1712. By the order of the King, Zollenstein Supreme Military Commissioner made those debts give back, which were equalized to the overfulfilled mining-works. It amounted to 12,473 Rhenish forints and 11 denarii, which from the Chamber handle 5370 forints and $801 / 2$ denarii over to the county tax-collector, but discharged an account of 7102 forints and 11 denarii. (From this sum was deducted 2978 forints and $61 / 2$ denarii for those "repartitio" obligation, which was fulfilled by the help of draught-horses coming from the settlements and manpower for digging of fishponds.) From the afore-mentioned 5370 forints and $801 / 2$ denarii, the following money were concerned with the Koháry demesnes ${ }^{16}$ :

\begin{tabular}{|l|l|c|}
\hline \multicolumn{1}{|c|}{ Name of the settlement } & Demesne & $\begin{array}{c}\text { The sum to be repaid for } \\
\text { the year of 1712/1713 }\end{array}$ \\
\hline $\begin{array}{l}\text { Ipolyvece (Hungary, Nógrád } \\
\text { County) }\end{array}$ & Čabrad' & none \\
\hline Dolná Vinica (Ipolyalsónyék) & Čabrad' & none \\
\hline Horná Vinica (Ipolyfelsőnyék) & Čabrad' & none \\
\hline Čelovce (Csall) & Čabrad' & 36 forints and 81 denarii \\
\hline Opava (Apafalva or Apova) & Čabrad' & 23 forints and 48 denarii \\
\hline Ipel'ské Úl'any (Ipolyfödémes) & Čabrad' & none \\
\hline $\begin{array}{l}\text { Čabradský Vrbovok } \\
\text { (Csábrágvarbók) }\end{array}$ & Čabrad' & 74 forints and 37 denarii \\
\hline Plášt'ovce (Palást) & Čabrad' & none \\
\hline
\end{tabular}

16 ŠABB, Hontianska župa, 3. škatul'a (Torzo spisov z rokov 1708-1756), tax account of the settlements of Hont County labouring for the Chamber of Banská Štiavnica for debt reductions (Krupina, 29 $9^{\text {th }}$ of June, 1715). 
The County and State Taxing of the Koháry Demesnes in Hont County ...

\begin{tabular}{|l|c|c|}
\hline Slatina (Szalatnya) & Čabrad' & none \\
\hline Dolné Semerovce (Alsószemeréd) & Čabrad' & none \\
\hline Vyškovce nad Ipl'om (Ipolyvisk) & Čabrad' & none \\
\hline $\begin{array}{l}\text { Presel'any nad Ipl'om } \\
\text { (Pereszlény) }\end{array}$ & Čabrad' & 17 forints and 25 denarii \\
\hline Medovarce (Méznevelő) & Čabrad' & 94 forints and $1 \frac{1}{2} 2$ denarii \\
\hline Svätý Anton (Szentantal) & Sitno & 140 forints and $1 \frac{1}{2}$ denarii \\
\hline Žibritov (Zsibritó) & Sitno & none \\
\hline Ilija (Illés) & Sitno & Sorints and 52 denarii \\
\hline Sitnianska (Szitnyatő or Steffoltó) & Sitno & 143 forints and $371 / 2$ denarii \\
\hline Krnišov (Kormosó) & Sitno & 290 forints and 91 denarii \\
\hline Beluj (Béld or Belluja) & Sitno & 262 forints and 79 denarii \\
\hline Prenčov (Berencsfalva) & Sitno & 37 forints and $831 / 2$ denarii \\
\hline $\begin{array}{l}\text { Sitnianska Lehôtka (Szitnyaliget } \\
\text { or Lehotka) }\end{array}$ & Sitno & none \\
\hline Devičie (Devicse) & Sitno & 1206 forints and $371 / 2$ denarii \\
\hline Altogether & &
\end{tabular}

But there were problems concerning the overpaying after the 1715 summer account. The inhabitants of Devičie were omitted from the list of the settlements which sent draught-horses to the mining works, so they sufferred a loss of 165 forints. Francis Bánhidy, Land-Stewart, had to detect the reason of it. It was cleared that Devičie gave draughthorses to the mining-works in only one occasion, but then so, that the village coacted with Žibritov and Krnišov, and the three settlements collectively sent the draught-horses to Banská Štiavnica. The village mayors of the other two settlements and the Captain of the County Villagers (in Hungarian: parasztvármegye kapitánya) confessed unamimously that the horses of Devičie really sent to the mining town together with the ones of Žibritov and Krnišov, and they affirmed that fact in writing. That could be found in the records of the former taxcollector, John Laszkáry. Thus, the 165 forints was due to Devičie, but that sum ought to be paid by the other two villages, because they had got it from the County. ${ }^{17}$

Occasionally, the Koháry-demesnes were obliged to do wagontraffic for military purposes. When the Campaign of Báčka was launched in 1716, by the order of the Sovereign, all of Hungarian Counties were obliged to send carts to the frontline for supplying the army. Hont County made decision that 180 carts fell upon Major-Hont from the obligatory 225, and after deducting the Mining Town areas, remained 176 carts (after converting the „dica” number of 31784 and 3/4). But the total "dica” number of the Koháry demesnes (5850) was includ-

\footnotetext{
${ }^{17}$ MNL-OL C $1298^{\text {th }}$ roll № 16219., (ŠABB, Archive of the Koháry Family, Pars V.), Francis Bánhidy's letter to Stephen Koháry (Čabrad', 24 $4^{\text {th }}$ of December, 1715).
} 
ed into that number, that equalled 27 and $1 / 2$ carts. (There is no archival resource about taking into consideration any exemption. $)^{18}$

THE ACQUIRING OF THE EXEMPTION OF THE KOHÁRY DEMESNES FROM THE FULFILLING OF THE GRATUITOUS LABOUR

There were customary orderliness in Hungary from the middle of the 16th century (from the forming of the Turkish Occupied Territories) that parliamentary laws ordered the counties to accomplish the free repair and building works of the border castles (gratuitus labor). The Magistrates - taking the total number of "portas” (the economical and producing plots of the County) as a basis - determined how many workers and carts would set going to the fulfilling. Although the Court War Council made several border castles demolished at the very beginning of the $18^{\text {th }}$ century, certain important fortresses (mainly along the riverside of the Danube) kept and continued to repair and maintain. ${ }^{19}$ Hont County was obliged to fulfill the gratuitous labour at two such strategically important fortresses: Buda and Esztergom.

During the Hungaria Eliberata (expulsion of the Ottoman forces from Hungary between 1683 and 1699), Stephen Koháry had continually tried to acquire exemptions from taxation for whichever demesnes, wherever was located ${ }^{20}$, and did the same from the 1710's, when he endeavoured to procure the exemption from the gratuitous labour for the two demesnes situated in Hont County. As any kind of exemption could be granted by the Sovereign, so Stephen Koháry appealed to Charles the Third (1711-1740) with his request. He wrote to Him that he knew very clearly that royal decree was issued to Hont County about the fulfilling of the gratuitous labour at Buda Fortress, but he would like to acquire exemption from the gratuitous labour for his own Čabrad' Castle and the demesne belonging to it. He reasoned his request so: in the ancestral family castle a garrison being loyal to Koháry served at the beginning of the Independence War named after Rákóczi, who corroborated their oath of allegiance to the Sovereign, and (in spite of every threatening) heroically defended the border castle during the $\mathrm{Ku}$ rucian blockade, moreover, they made sallies against the besiegers again and again. But after a certain time, they were compelled to hand Čabrad' over to the Kurucs, because the troops being loyal to Francis Rákóczi durative occupied Lower Hungary to Nitra (Nyitra), amid the Mining Towns, and the border castles supposed to defend them (Levice

\footnotetext{
${ }_{18}$ MNL-OL C $1123^{\text {rd }}$ roll № 7072., (ŠABB, Archive of the Koháry Family, Pars V.), John Kovács's letter to Stephen Koháry (Nenince, $28^{\text {th }}$ of August, 1716).

19 OROSS, 2006, pp. 1441-1473.

${ }^{20}$ KOMJÁTI, 2018, pp. 74-82.
} 
The County and State Taxing of the Koháry Demesnes in Hont County ...

[Léva], Bzovík [Bozók], Halič [Gács] and Modrý Kameň [Kékkő]), and were not able to replenish the food and ammunition supplies. The $\mathrm{Ku}-$ rucs, making use of the manpower of the brick-layers carried from Banská Bystrica (Besztercebánya) and Banská Štiavnica (Selmecbánya) and the bondsmen living in the neighbourhood, immediately demolished the bastions and the walls, moreover, the 15 cannons, the 2 mortars and all kind of guns and ammunitions were taken away or destroyed. The rebel occupation army totally devastated and pillaged Čabrad' and its surroundings, the civil inhabitants were compelled to escape before them, they made the spot uninhabitable, so the demesne became unfit for the agricultural life, such as the other Hont County demesne centre of the Koháry's, castle Sitno (Szitnya). As an entire reconstruction and rebuilding would need throughout the whole demesne, Koháry asked the Sovereign that the settlements belonging to Čabrad' would be exemptioned from the gratuitous labour and a diploma (littera exemptionalis) would be issued about it, and at last, the Sovereign would inform the Hungarian Royal Court Chancellory and the Court War Council. Koháry also drew the Sovereign's attention to the fact that the Demesne of Čabrad' formerly had the exemption from the gratuitous labor on the basis of the $7^{\text {th }}$ law article of $1681 .{ }^{21}$ Stephen Koháry also wrote another application, in which he advanced before the Sovereign in the same way the devastation of Čabrad' during the rebellion period, but he not only requested the settlements' exemption from the gratuitous labour imposed on Hont County, but also the rebuilding of the castle by the manpower of the bondsmen. He also alluded to the $7^{\text {th }}$ law article of 1681 , and he asked for the issuing of the diploma of exemption again, and the Sovereign's notice about it toward the before-mentioned two organizations. ${ }^{22}$

By the royal diploma of exemption, Hont County accepted the Koháry demesnes' exemption from the gratuitous labour, but with a condition that the exemption would be claimed on each occasion when the County distributed the ratio of the fulfilling among the county settlements, so as not to be redundantly encumbered. Stephen Koháry as Lord-Lieutenant of Hont County ordered Lucas Pécsy, the SecondDeputy-Lieutenant (substitutus vice-comes), that he would announce the claim to the exemption of the Demesne of Čabrad' from the gratuitous labour before the General Assembly held at Šahy (Ipolyság) on $7^{\text {th }}$

\footnotetext{
${ }^{21}$ MNL-OL C 1082nd roll № 5914., (ŠABB, Archive of the Koháry Family, Pars V.), Stephen Koháry's application for exemption to Sovereign Charles the Third (undated, but on the strength of its content written between 1711 and 1715).

22 In the same place, № 5919, Stephen Koháry's application for exemption to Sovereign Charles the Third (undated, but on the strength of its content written between 1711 and 1715).
} 
of May. Lucas Pécsy did it, and reported to the Lord-Lieutenant that the County accepted the exemption in principle, and wrote a letter about it. ${ }^{23}$ Francis Bánhidy, Land-Stewart, also wrote to Koháry about that General Assembly of Šahy, and it is cleared from the letter that the document of the County suggested the proposal of the exemption before the Diet, and if it would be assented and carried there, the County would conform to it. But even if the Diet would not make decision about it, the County accepted the exemption, but the deficit derived from the deducted "porta” numbers would be passed to the other county settlements' debit. ${ }^{24}$

On $18^{\text {th }}$ of May, General Regall, the Commander of Buda Fortress, admonished the Counties obliged to fulfill the gratuitous labour (Esztergom, Fejér, Hont, Nógrád and Pest-Pilis-Solt ${ }^{25}$ ) to send delegations to him for discussing the conditions of fulfilling. ${ }^{26}$ On $26^{\text {th }}$ of May, Stephen Koháry asked to Regall to take the exemption of the Demesne of Čabrad' into consideration. On 28 $8^{\text {th }}$ of May, Regall responded to Stephen Koháry that he would aim to conforming himself to the request. ${ }^{27}$

On $1^{\text {st }}$ of June, the delegates of Hont County appeared in Buda for the discussion about the fulfilling of the gratuitous labour, and also declared the claim to the exemeption of the Koháry demesne. Regall wrote to Stephen Koháry on the same day, that he come to an agreement with the delegates: though the demesne would be free from the fulfilling, but the quantity of the "porta” numbers deducted from the County due to the exemption would be passed to other settlements' debit. ${ }^{28}$

Leslie Dobay, County Tax-collector (perceptor), also informed Stephen Koháry about this $1^{\text {st }}$ of June agreement. He and Samuel Blaskovits went on errands in Buda, as they were just about to compromise with Vorstern, Supreme Military Commissioner, about the cost of the winter quarters, but when they became aware of appearance of their county compeers in Buda about the arranging the gratuitous labour (and because Regall and Vorstern usually took part together in the agreement

\footnotetext{
${ }^{23}$ MNL-OL C $1123^{\text {rd }}$ roll № 7086., (ŠABB, Archive of the Koháry Family, Pars V.), Lucas Pécsy's letter to Stephen Koháry (Krupina, $14^{\text {th }}$ of May, 1715).

${ }^{24}$ MNL-OL C 987th roll № 7160., (ŠABB, Archive of the Koháry Family, Pars IV.), Francis Bánhidy's letter to Stephen Koháry (Čabrad', 15 $5^{\text {th }}$ of May, 1715).

${ }^{25}$ Here can be found the number of the Counties directed to Buda Fortress in 1715: MNLOL C $1192^{\text {nd }}$ roll № 8378., (ŠABB, Archive of the Koháry Family, Pars V.), John Kovács's letter to Stephen Koháry (Nenince, $2^{\text {th }}$ of March, 1715).

${ }^{26}$ MNL-OL C $1123^{\text {rd }}$ roll № 7123., (ŠABB, Archive of the Koháry Family, Pars V.), General Regall's letter to Fejér County (Buda, $18^{\text {th }}$ of May, 1715.). The letters written to each Counties might be similar to this one.

${ }^{27}$ MNL-OL C 1082nd roll № 5910., (ŠABB, Archive of the Koháry Family, Pars V.), General Regall's letter to Stephen Koháry (Buda, $28^{\text {th }}$ of May, 1715).

${ }^{28}$ In the same place, № 5911., General Regall's letter to Stephen Koháry (Buda, $1^{\text {st }}$ of June, 1715).
} 
concerning the gratuitous labour), so Dobay and Blaskovits joined to the negotiators. Though Regall wanted nothing obligation from Esztergom County, but - by the order of Charles the Third - the other four counties were encumbered with enormous tasks. For example, Hont County was supposed to send 19 carts and 161 labourer man for the renovation works of Buda Fortress. When the delegates mentioned the exemption of the Demesnes of Čabrad' and Sitno, then Regall firstly disapproved of it, and he did not accept it as far as a royal diploma would be arrived about it. But when the county negotiators were just about to leave the room, Regall suddenly asked them back, and concerned himself about the number of the "portas" in the two demesnes which would be deducted from the county quantity. Dobay and his compeers were not able to know that, because the census of the County was not there by them, but Regall did not care for the answer at all, and suddenly announced: however many the number of the "portas”, he countenanced the deduction from the repartition quantity imposed on Hont County, but that number would be passed to other county settlements' debit. Dobay also wrote to Koháry that he would reported about Regall's decision before the County Magistrate at the Partial Assemly held on $7^{\text {th }}$ of June. ${ }^{29}$ On $5^{\text {th }}$ of June, Stephen Kelkó, Deputy-Lieutenant, and Gabriel Bory, County Notary (both delegated to the Diet of Bratislava), issued an offical document for Stephen Koháry and his family. They announced in the document that on the basis of the „porta” number correction specified by the Palatine on the Diet session, Hont County had got 179 portas, and 30 portas were concerned about the Koháry demesnes from it; but they would try to concert with the competent persons about the reduction. Hont County would issue a new document about the consequence to the Lord-Lieutenant after the end of the Diet. ${ }^{30}$ Then Stephen Koháry asked the exemption of the demesnes in writing from Vorstern, Supreme Military Commissioner, who responded that he exempted by courtesy the demesnes from the gratuitous labour of Hont County (sending carts and workers), and pronounced that it was fulfilled for the 1715 year, that is to say, accepted the entire county obligation. ${ }^{31}$

\footnotetext{
${ }^{29}$ MNL-OL C $1191^{\text {st }}$ roll № 8370., first letter (ŠABB, Archive of the Koháry Family, Pars V.), Leslie Dobay's letter to Stephen Koháry (Krupina, $5^{\text {th }}$ of June, 1715.). The same also can be found here: MNL-OL C 1082 ${ }^{\text {nd }}$ roll № 5913., (ŠABB, Archive of the Koháry Family, Pars V.), extract of László Dobay's letter.

${ }^{30}$ In the same place, № 5924., the official document of the delegates of Hont County delegated to the Diet of Bratislava (Bratislava, $5^{\text {th }}$ of June, 1715).

${ }^{31}$ In the same place, № 5912., Johann Matthias Vorstern’s letter to Stephen Koháry (Pest, $15^{\text {th }}$ of June, 1715 ).
} 
It can be known why, but the County directed six oxes and two carts from the Demesne of Sitno to Buda due to the fulfilling the gratuitous labour. However, it sent them back at the and of the year, moreover, gave a compensation of 73 forints and 85 denarii to Francis Bánhidy, LandStewart, by reason of their deficiency from the agricultural works. ${ }^{32}$

In the year of 1716, Stephen Koháry also requested the official document from the County about the „porta” number of the Demesne of Čabrad' for the reason of the constant efficiency of the exemption and its taking into consideration again. So he directed Francis Bánhidy to go to the General Assembly held at Banská Štiavnica. At the request of Bánhidy, being on behalf of the Landlord officially and legally, Hont County (taking the documents of the county archive into consideration and applying to the ordinary method) issued a new document, and according to it, the Demesne of Čabrad' had 23 and $1 / 4$ portas after an arithmetical accuracy scaling. 33

In the year of 1723, Stephen Koháry gave an order to Francis Bánhidy, Land-Stewart of the Demesne of Čabrad' and Sitno, through Michael Balogh, Land-Stewart, that he would not send only one bondsman at all to the gratuitous labour obligation of Buda. And the Landlord gave Michael Balogh the task that he would ask Gabriel Bory, Hont County Notary, that he would look the royal diploma up from the county archive, which contained the exemption of the demesnes from the gratuitous labour. ${ }^{34}$

In the spring of 1724, Stephen Koháry commissioned his grandnephew Andrew Koháry to announce the claim to the exemption of the Demesne of Čabrad' from the gratuitous labour at the nearest General Assemly, and requested an official document, that the County would not really enrol the demesne into the contributory „portas”, as an effectual royal diploma had been issued about the exemption. On $8^{\text {th }}$ of March, Nicholas Dvornikovics, Deputy-Lieutenant (vice-comes), informed Andrew Koháry that Hont County would be ought to come to a decision about the fulfilling of the gratuitous labour, and mainly because of it, a General Assemly would be held on $28^{\text {th }}$ of March at Plášt'ovce. ${ }^{35}$ The young Count lost his two small children during one month in various

\footnotetext{
32 MNL-OL C $1298^{\text {th }}$ roll № 16234., (ŠABB, Archive of the Koháry Family, Pars V.), Francis Bánhidy's letter to Stephen Koháry (Čabrad', 15 th of December, 1715).

${ }^{33}$ MNL-OL C $1082^{\text {nd }}$ roll № 5923., (ŠABB, Archive of the Koháry Family, Pars V.), document of Hont County about the „porta” number of the Koháry demesnes (Banská Štiavnica, $10^{\text {th }}$ of March, 1716).

${ }^{34}$ MNL OL C $756^{\text {th }}$ roll № 408., (ŠABB, Archive of the Koháry Family, Pars IV.), Michael Balogh's letter to Stephen Koháry (Bátorová, $28^{\text {th }}$ of May, 1723).

35 MNL-OL C $1298^{\text {th }}$ roll № 16191., (ŠABB, Archive of the Koháry Family, Pars V.), Andrew Koháry's letter to Stephen Koháry (Svätý Anton, 9 $9^{\text {th }}$ of March, 1724).
} 
The County and State Taxing of the Koháry Demesnes in Hont County ...

contagious illnesses (a little boy named Francis passed away on $10^{\text {th }}$ of February out of his three living children ${ }^{36}$, then a little daughter died of the contagious illness on $10^{\text {th }}$ of $\mathrm{March}^{37}$ ), so he willingly threw himself into the county politics, as he tried to alleviate his dolour in that way.

On the second day of the General Assembly held at Plášt'ovce, on $29^{\text {th }}$ of March, the acceptance of the exemption of the Koháry demesnes from the gratuitous labour took place. Right away after the reading of the royal decree about the fulfilling of the gratuitous labour, Koháry's commissioned persons rose to speak: firstly Francis Bánhidy requested the acceptance of the exemption, then Andrew Koháry announced the claim to the same. The County took their request into consideration, as there really were documents and diplomas about the exemptions from Prince Eugene of Savoy, from General Regall, former Commandant of Buda Fortress, and from Vorstern, Supreme Military Commissioner. Thus, the County Magistrate deduced the $231 / 4$ "porta” numbers of the Demesne of Čabrad' from the obligatory county quantity, and the demesne was pronounced to be tax-free and untouchable. A county decision was also made about soon sending of John Kovács and Wolfgang Gosztonyi to Buda so as to compromise with Commandant concerning the conditions of the fulfilling of the gratuitous labour. ${ }^{38}$ Andrew Koháry informed Stephen Koháry about that decision, and also about, that the County would not want the deduced „porta” numbers to be passed to other county settlements' debit, and endeavoured to argue the Commandant into totally cancelling them. ${ }^{39}$

On the next General Assembly held at Bátovce (Bát) on $8^{\text {th }}$ of May, the County factually made decision about County Judiciary Assessor (Tabulæ Regiæ Iudiciariæ Assessor) John Kovács's and District Guider (iudex nobilium) Wolfgang Gosztonyi's sending to Buda so as to compromise with the Commandant, and most of all, they would refer the matters of the exemption of the Demesnes of Čabrad' and Sitno and their numerically 23 and $1 / 4$ deduction of „porta” numbers from the obligatory fulfilling of the county to him. ${ }^{40}$ On the next day morning,

\footnotetext{
${ }^{36}$ MNL-OL C 1064th roll № 5636., (ŠABB, Archive of the Koháry Family, Pars V.), Andrew Koháry's letter to Stephen Koháry (Svätý Anton, 13 ${ }^{\text {th }}$ of February, 1724).

${ }^{37}$ MNL-OL C 1298 th roll № 16192., (ŠABB, Archive of the Koháry Family, Pars V.), Andrew Koháry's letter to Stephen Koháry (Svätý Anton, 12 th of March, 1724).

38 ŠABB, Hontianska župa, 4. škatul'a (Kongregačné zápisnice z rokov 1691-1754), minutes of General Assembly of Hont County (Plášt'ovce, 28-29 th of March, 1724).

${ }^{39}$ MNL-OL C 1082 $2^{\text {nd }}$ roll № 5918., (ŠABB, Archive of the Koháry Family, Pars V.), Andrew Koháry's letter to Stephen Koháry (Svätý Anton, $2^{\text {nd }}$ of April, 1724).

40 ŠABB, Hontianska župa, 4. škatul'a (Kongregačné zápisnice z rokov 1691-1754), minutes of General Assembly of Hont County (Bátovce, $8^{\text {th }}$ of May, 1724): „...Ex Quotta huic Comitatui obvenientium ordinatorumque Curruum \& Operariorum tantumdem modali-
} 
John Kovács stayed at Bátovce yet, and informed Koháry about the county delegation and they would try to argue the Commandant of Buda Fortress into accepting the exemption of the demesnes. ${ }^{41}$ On that day, the two delegates really travelled to Buda, and the agreement was came about, because Count Heinrich Joseph Daun immediately wrote a letter to Stephen Koháry. He wrote that he accepted the exemption of the Demesne of Čabrad' from the fulfilling of the gratuitous labour presented on the negotiation by John Kovács both orally either written form, but only exclusively having regard to Koháry's own person and his ancestors' virtues. But he declared that he would want to lay claim to the other gratuitous labour fulfilling obliged for Hont County, and desired to be brought into effect as soon as possible. ${ }^{42}$

In accordance with the mandate of the Sovereign and the Hungarian Royal Locum-tenens Council issued on $6^{\text {th }}$ of May, Hont County was to be obliged to fulfilling the gratuitous labour at Esztergom Fortress and being discharged from the one belonged to Buda Fortress. The members of the General Assembly congregated at Hontianske Tesáre (Teszér) made that decision that the Demesnes of Čabrad' and Sitno would remain exempted from the newly imposed free-work obligation (so much as former to Buda), and the half cart and the one worker (by the ratio derived from the 23 and $1 / 4$ „porta” number) would not be added to the obligatory five carts and ten workers. (The three mining towns also were exempted from the gratuitous labour with the same ratio, so Hont County would like to sent four carts and eight workers to Esztergom Fortress.) The General Assembly made a decision that Wolfgang Gosztonyi would have to travel to Buda, and present the royal order about the redirection of the gratuitous labour to the Commandant. But another decision was made that a delegation being consisted of John Újvendégi Canon of the Archibishopric of Esztergom, Nicholas Dvornikovics, Deputy-Lieutenant, and Wolfgang Gosztonyi, District Guider, would go to

tate antecedenter observata defalcaturum, quantum Bonis Csábrágiensibus \& Szittnensibus ex portis $231 / 4$ constantibus de justo competere et obvenire comperietur...".

${ }^{41}$ MNL-OL C 1191st roll № 8356., (ŠABB, Archive of the Koháry Family, Pars V.), John Kovács's letter to Stephen Koháry (Bátovce, $9^{\text {th }}$ of May, 1724).

${ }^{42}$ MNL-OL C 988th roll № 7359., (ŠABB, Archive of the Koháry Family, Pars IV.), Count Heinrich Josef Daun's letter to Stephen Koháry (Buda, 9th of May, 1724.): „...Compa-ruerant coram me exmissi e gremio Inclyti Comitatus Honthensis Perillustres Domini Ioannes Kovacz et Wolfgangus Gosztonyi et petitum Excellentiæ Vestræ ratione immunitatis bonorum Ejus in comitatu Hontensi, et eorum portarum defalcationis ex quanto totius communitatis tam Scriptotenus medio literarum, quam præfatus Dominus Kovacz Mihi oratenus declaraverat; cui petito, quemadmodum ob specialem considerationem erga personam Excellentiæ Vestræ jam temporibus antecessoris mei condescensum fuerat, Ita et Ego libenter annui; Eandem solummodo perquam officiose rogans, Inclyto sibi concredito Comitatui demandare dignetur, quatenus Reliquam quotam præstandi quantocius suppeditare non moreturi..." 
The County and State Taxing of the Koháry Demesnes in Hont County ...

the Commandant of Esztergom Fortress and announce (among others) the claim to the exemption of the two demesnes and their deduction from the obligatory "porta” number by the proper ratio. ${ }^{43}$

The light is thrown on the fact by the letter of Andrew Koháry written few days later, that on the General Assemly at Hontianske Tesáre, John Kovács reported his hard negotiation with the Commandant of Buda about the exemption of the Koháry demesnes. The Assembly's main point of controversy was that the „porta” numbers of the three mining towns were included to the obligatory county quantity by the order of the the Hungarian Royal Locum-tenens Council, but, nevertheless, the County gave the exemption to them, same as to the Koháry demesnes. But the Magistrate was afraid of the passing the deficient „porta” numbers to the County by the order of the higher authorities, so they asked Stephen Koháry's mediation through his greatnephew. ${ }^{44}$

Stephen Koháry wrote to Maximilian Schuchknecht, the Commandant of Esztergom Fortress, concerning the exemption of the Demesnes of Čabrad' and Sitno on $28^{\text {th }}$ of May, and acquainted him, that he had procured royal diploma for the above-mentioned demesnes, and it had already been accepted by the County. In his reply, Schuchknecht advanced that he would not want to cause Koháry damage dispensing with the exemption, and he willingly approved that Hont County would fulfill the obligatory gratuitous labour of Esztergom with reducing of a half from the carts and one person from the workers on the basis of the „porta” number by the proper ratio. ${ }^{45}$

After all, Hont County bought off the gratuitous labour of Esztergom: on the occasion of the county committee of tax determination (censuralis deputatio) celebrating on $31^{\text {st }}$ of July, the County Tax-collector put an imposition of 4 forints on each "dica”, but it was not appertained to the two Koháry demesnes because of the exemption. That entry was

\footnotetext{
43 ŠABB, Hontianska župa, 4. škatul'a (Kongregačné zápisnice z rokov 1691-1754), minutes of General Assembly of Hont County (Hontianske Tesáre, $13^{\text {th }}$ of June, 1724).

${ }^{44}$ MNL-OL C 1298 th roll № 16200 ., (ŠABB, Koháry-család levéltára, Pars V.), Andrew Koháry's letter to Stephen Koháry (Svätý Anton, $18^{\text {th }}$ of June, 1724).

${ }^{45}$ MNL-OL C 1082 ${ }^{\text {nd }}$ roll № 5916., (ŠABB, Archive of the Koháry Family, Pars V.), Maximilian Schuchknecht's letter to Stephen Koháry levele (Esztergom, 20th of June, 1724.): „...Excellentiæ Vestræ literas, Viennæ sub 28 præteriti Mensis Maÿ exaratas, quibus Excellentia Vestra, intuitu operariorum ex Curruum ex parte Inclyti Comitatus Honthensis ad Fortality nostri reparationem præstandorum, me de immunitate a Sua Sacratissima Cæsarea Regiaque Majestate, Super Bonis in prælibato Inclytu Comitatu sitis, iam pridem impetrata, certiorem reddere dignata est, debito cum respectu percepi. Prout ergo Excellentiæ Vestræ in hocce clementissime acquisito Indulto nullatenus præjudicare desidero. Ideo etiam libenter admisi, ut Inclyto Comitatus Honthensis portas Bona nimirum Excellentia Vestra concernentes defalcare, sicque a repartito ac injuncto Numero Operarium unum, ac medium currum minus præstare ausit ac possit...".
} 
not implicated to the county income (introitus), but according to the decision of the committee, soon the County Tax-collector would have to make a separate report for the County Magistrate. ${ }^{46}$ Amery Foglár, Deputy County Notary, reported before the General Assembly held on $7^{\text {th }}$ of August about the decisions of the "censuralis deputatio" of Bátorová (Bátorfalu), amid the exemption from the gratuitous labour of the two Koháry demesnes, which was accepted by the County anew. ${ }^{47}$

In the spring of 1726, the Hungarian Royal Locum-tenens Council wrote two letters to Hont County that would be supposed to send 22 workers and 9 carts for fulfilling the obligatory gratuitous labour at Esztergom Fortress. The General Assembly held at Hontianske Tesáre on $8^{\text {th }}$ of May made a decision that a county delegation would be sent to the Commandant of Esztergom Fortress. One of the negotiation items contained that the delegates tried to persuade him that lesser carts and workers would be directed to the fortress due to the exemption of the Demesnes of Čabrad' and Sitno. ${ }^{48}$ According to the instructions of the county delegates, they was to impart to the Commandant on $13^{\text {th }}$ of May, that due to the exemption granted for Stephen Koháry (which was equally concerned with the repair works either at Buda, or at Esztergom), the county „porta” numbers were decreased with 23 and $1 / 4$, and equalled 3 workers and 1 cart after the converting. So the County would send 19 workers and 8 carts to Esztergom, what the Commandant would be disposed to take into account and accept. ${ }^{49}$ It is lightened from the Commandant's reply that he sceptically heard the statement of the delegation out, because he had no notion about how the obligatory quantity specified by the Hungarian Royal Locum-tenens Council had been decreased by more than its half, and the County wanted further

\footnotetext{
46 ŠABB, Hontianska župa, 4. škatul'a (Kongregačné zápisnice z rokov 1691-1754), minutes of the tax-determination committee of Hont County (Bátorová, 31 $1^{\text {st }}$ of July, 1724). 47 ŠABB, Hontianska župa, 43. škatul'a (Determinačné protokoly z rokov 1724-1731), minutes of General Assembly of Hont County (Dolné Plachtince, $7^{\text {th }}$ of August, 1724).

${ }^{48}$ In the same place, minutes of General Assembly of Hont County (Hontianske Tesáre, $8^{\text {th }}$ of May, 1726).

${ }^{49}$ MNL-OL C 1082 ${ }^{\text {nd }}$ roll № 5926. and C $1292^{\text {nd }}$ roll № 15199., (ŠABB, Archive of the Koháry Family, Pars V.), negotiating instructions for the delegation of Hont County and the reply of the Commandant of Esztergom concerning to that (May, 1726): „....Siquidem Bona Excellentissimi ac Illustrissimi Domini Comitis Stephani Kohárÿ de Csábrágh, \& Szittnya Iudicis Curiæ Regiæ titt. \& Familiæ Suæ Csábrághiensia \& Szittnensia ab onere gratuitorum laborum per Superiores Instantias exempta sint, ex prævio assignatis 9 curribus unus, 22 autem manualibus tres secundum calculum arithmeticum ad Portas 23 \& 1/4. attactis exemptis Suæ Excellentiæ Bonis adhærentes instar modalitatis Annis Superioribus in præstatione similium Gratuitorum Laborum tum ad Budense tum hoc Strigoniense fortalitia practicatæ demendi, Inputandique, \& non nisi residui currus octo, \& 19 Laboratores per Comitatum administrandi venient..."
} 
The County and State Taxing of the Koháry Demesnes in Hont County ...

deductions from it, due to the exemption of the Koháry demesnes. The Commandant accepted the of principle facts, but he answered the delegates that he would make inquiries from the higher authorities about whether the Koháry demesnes really enjoyed any exemption from the gratuitous labour? He said the delegates that he would also make inquiries about the obligatory specified quantity, because his knowledge, Hont County was obliged to send 48 workers and 20 carts for the year of 1726 , and not 22 workers and 9 carts as the delegates pronounced. While the reply of the Hungarian Royal Locum-tenens Council would not resolve his scruple, the Commander demanded the first, numerically bigger version from the County..$^{50}$

The County Notary reported before the following General Assembly held at Presel'any nad Ipl'om on $20^{\text {th }}$ of May, that the tax reduction concerned with the Koháry demesnes had not been accepted by the Commandant of Esztergom. So the Deputy-Lieutenant overtook that he would personally see Stephen Koháry about the problem, and then by the help of his mighty of magnate, would try to procure a new possibility of negotiation with the Commandant of Esztergom, where the delegates would prove the fact of the exemption by original documents issued by Prince Eugene of Savoy and other higher authorities. As the documents would be ready, the delegation (consists of the County Notary and the Land-Stewart of the Chapter of Esztergom) immediately started off, and its task would be to make constant efforts for getting the acceptance of the reduced tax quota across to the Commandant. ${ }^{51}$ And when the Commandant urged the County for the fulfilling with this letter dated from $22^{\text {nd }}$ of June, the Magistrate responded, that only 8 carts and 19 workers would be sent to Esztergom by the $7^{\text {th }}$ of July, because that quantity was the obligatory in its opinion, and it would be just realized, when the proportioned part would be deducted which was derived from the Demesnes of Čabrad' and Sitno. ${ }^{52}$

It seems that Maximilian Schuchknecht, Commandant of Esztergom Fortress, did not accept the fulfilling way of the County, because Stephen Koháry applied to Prince Eugene of Savoy, Chairman of the Court War Council. In his letter of supplicant, he wrote that an exemption had been granted by the Charles the Third for his Demesnes of Čabrad' and Sitno, and General Regall had taken it into account and had accepted Hont County's gratuitous labour fulfilling with the deduction of the "quota"

\footnotetext{
50 In the same places.

51 ŠABB, Hontianska župa, 43. škatul'a (Determinačné protokoly z rokov 1724-1731), minutes of General Assembly of Hont County (Presel'any nad Ipl'om, 20 $0^{\text {th }}$ of May, 1726).

52 In the same place, minutes of General Assembly of Hont County (Dolné Príbelce, $25^{\text {th }}$ of June, 1726).
} 
number of the demesnes. When the County's obligatory gratuitous labour had been re-directed to Esztergom in 1724, then in that year and in 1725, Maximilian Schuchknecht also accepted the exemption. But in the year of 1726, he rejected to take it into account, and demanded the initial quota numbers specified by the Hungarian Royal Locum-tenens Council. So the Lord-Lieutenant asked Prince Eugene of Savoy to give an order to Schuchknecht for conforming with the royal diploma, besides, the Chairman would be kind enough to forward Koháry's application to the Hungarian Royal Court Chancellory and the Hungarian Royal Locum-tenens Council, so as both would be informed about it, examine its content to the bottom, and make arrangements for the exercise of the exemption. ${ }^{53}$ Reading the reply of the Court War Council, that in course of the reconciliation with the above mentioned two offices, it was lightened that the military organization was not authorized either to specifying the gratuitous labour fulfilling, or to modifying it, because any of them was exclusively depended on the decision of the Hungarian Royal Locum-tenens Council. Thus, Hont County would not contradict, instead of it, would do as ordered.54

After a few time, The Hungarian Royal Locum-tenens Council ascertained that the „porta” number of $23 \frac{1 / 4}{4}$ concerned with the Koháry de-

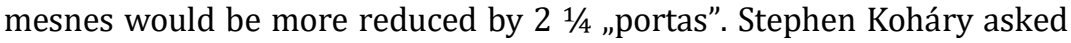
the County Magistrate to issue a legal and certified document (testimonialis) about that fact, which was really prepared for him. ${ }^{55}$

\section{List of References}

KOMJÁTI Zoltán Igor: Koháry István birtokvédelmi törekvései a Hungaria eliberata idején (1686-1699). In: Dominium IV. (A földesurak szerepe), a 2016. szeptember 29-én, Miskolcon megtartott 8. Országos Uradalomtörténeti Konferencia kötete. ed. É. Szirácsik, Budapest : Unicus Műhely Kiadó, 2018, pp. 74-82.

Magyarország története 4/1. (1686-1790). eds. Gy. Ember - G. Heckenast, Bu-dapest : Akadémiai Kiadó, 1989.

MNL-OL = Magyar Nemzeti Levéltár - Országos Levéltára Budapest

OROSS, András: Végvárakból kaszárnyák (A Budai Kamarai Adminisztráció szerepe Magyarország új katonai berendezésében a 17-18. század fordulóján). In: Századok. 140. vol., 6. no., 2006, pp. 1441-1473.

POÓR, János: Megbékélés és újjáépítés: 1711-1790. Budapest : Kossuth Kiadó, 2009.

\footnotetext{
${ }^{53}$ MNL-OL C $1230^{\text {th }}$ roll № 12347., (ŠABB, Archive of the Koháry Family, Pars V.), Stephen Koháry's application to Prince Eugene of Savoy (September-October, 1726).

${ }^{54}$ In the same place. - The reply of the Court War Council can also be found here: MNLOL C $1082^{\text {nd }}$ roll № 5925.

55 ŠABB, Hontianska župa, 43. škatul'a (Determinačné protokoly z rokov 1724-1731), minutes of General Assembly of Hont County (Dolné Rykynčice, $17^{\text {th }}$ of February, 1727).
} 
The County and State Taxing of the Koháry Demesnes in Hont County ...

SZIRÁCSIK, Éva: Gazdálkodás a Koháryak Nógrád vármegyei központú birtokain (1647-1731). Budapest: Magyar Mezőgazdasági Múzeum, 2017.

ŠABB = Štátny archív v Banskej Bystrici.

\section{Zhrnutie:}

\section{Stoličné a štátne zdanenie Koháryovských rodových majetkov v Hontianskej stolici v 2. a 3. decéniu 18. storočia}

Štúdia približuje podobu, výšku a spôsob výberu daní pre potreby štátnej administratívy a armády na príklade dvoch rodových majetkov Koháryovcov v bývalej Hontianskej stolici. Autor analyzuje v troch častiach štúdie tri rôzne formy zdanenia: vojenskú daň v podobe tzv. porcií, štátnu daň vyberanú stoličnými úradníkmi a napokon povinnost’ dobrovol’nej práce („gratuitus labor") poddaných na stavbe pohraničných opevnení a hradov. Pri analýze autor vychádza zo súpisov zaplatených daní - prípadne z evidencie daňových nedoplatkov a pôžičiek - hontianskych obcí, ktoré patrili do dvoch panstiev rodu Koháryovcov v Hontianskej stolici (Čabradské, ležiace v Bzovíckom slúžnovskom okrese, a Sitnianske, ležiace v Štiavnickom slúžnovskom okrese). Sledovaným obdobím je 2. a 3. decénium 18. storočia, kedy bol hontianskym županom Štefan Koháry (1649 - 1731). V prvej časti autor komparuje daňové odvody rôznych obcí oboch Koháryovských panstiev pre potreby armády v podobe tzv. porcií (delili sa na tzv. ústne a konské - teda na dávky určené na vyživovanie vojakov a ich koní). Zo zistených údajov vyplýva, že daňové zat'aženie bolo značne vysoké, poddaní ho len s vel'kými t'ažkost'ami platili, často len s pomocou zadlžovania sa. V nasledujúcej časti si autor všíma problematiku finančnej kompenzácie poddaných zo Sitnianskeho panstva za ich prácu a poskytnutie koní a povozov pre Banskoštiavnickú banskú komoru v rokoch 1708 - 1712. Zo zistení vyplýva, že banská komora poddanské obce vyplatila s oneskorením niekol'kých rokov, a to tým spôsobom, že splatila podlžnosti obcí, ktoré im vznikli pri platení vojenskej dane (porcie). V tretej časti štúdie je analyzovaná povinnost' dobrovol’nej práce poddaných na stavbe pohraničných opevnení. Z hontianskych obcí mali poddaní povinnost' obnovovat' opevnenia Budína a Ostrihomu. Gróf Štefan Koháry od cisára Karola VI. získal oslobodenie od tejto povinnosti pre svojich poddaných na Čabradskom panstve. Argumentoval najmä tým, že počas povstania Františka II. Rákociho ostala posádka hradu Čabrad' verná panovníkovi, a ked' neskôr musela hrad opustit', bol zničený Rákociho kurucmi. Hontianska stolica s oslobodením poddaných od tejto povinnosti súhlasila, musela však čast' chýbajúcich pracovných síl získat' v iných sídlach. Autor venuje pozornost' najmä administratívnym úkonom, ktoré boli spojené so schválením a praktickým aplikovaním tejto výnimky z poddanských povinností na stoličnej a vládnej úrovni (stoličná správa, Dvorská vojenská rada, vojenské velitel’stvá). 